\title{
Environmental concerns and attitudes of tourists towards national park uses and services
}

\author{
Seyed Ahmad Moumen Ghazvini ${ }^{\text {a,* }}$, Dallen J. Timothy ${ }^{\text {b,c }}$, João Sarmento ${ }^{\text {d,e }}$ \\ a Universitat Autònoma de Barcelona, Department of Geography and School of Tourism \& Hotel Management, Barcelona, Spain \\ ${ }^{\mathrm{b}}$ School of Community Resources and Development, Arizona State University, USA \\ c School of Tourism and Hospitality, University of Johannesburg, South Africa \\ d University of Minho, Geography Department, Guimarães, Portugal \\ e Communication and Society Research Centre, University of Minho, Portugal
}

\section{A R T I C LE IN F O}

Keywords

Tourist attitudes

Environmental concerns

Protected areas

Ecotourism

National parks

Appropriate use

\begin{abstract}
A B S T R A C T
Human behaviour plays a significant role in preserving or degrading the environment. To put into practice the notion of 'use without abuse', it is vital for national park managers to be cognizant of tourists' attitudes and beliefs, which in turn affect their behaviours. This study evaluates the attitudes of domestic and international tourists regarding the appropriate uses of national parks, as well as their environmental concerns. The study also addresses the relationship between environmental concerns and tourists' perceptions of the appropriateness of activities, facilities and services inside national parks. A total of 379 domestic $(\mathrm{n}=175)$ and international ( $\mathrm{n}=204$ ) tourists participated in this study at Taman Negara (national park), Malaysia. The findings reveal that domestic tourists perceive motorised activities, accommodation and service facilities, and sport/recreation facilities as more acceptable than international tourists do. The results of this study may help managers of protected areas in Malaysia and other developing countries play a stronger role in improving visitors' awareness of environmental challenges and acceptable behaviours and activities.

Management implications: This study reinforces established ideas for national park and protected area management:
\end{abstract}

- Tourists' environmental concerns can negatively affect their attitudes towards the appropriateness of activities, facilities, and accommodations within national parks.

- The attitudes of various groups of visitors regarding human uses of national parks vary between different cultural backgrounds.

- To reduce the impact of tourism activities on the natural environment and minimising the environmental degradation of protected areas, decision-makers should incorporate into their management plans the environmental concerns and attitudes of visitors who use protected areas and national parks.

\section{Introduction}

Tourism involves people traveling to destinations with the intention of satisfying a need through an activity or combination of activities (Vanhove, 2010). Over time, as certain activities grow and numbers of people increase, many types of tourism have evolved into mass tourism. Others have emerged as alternatives to mass tourism.
The original aim of alternative tourism was to be more compatible with the destination's social and natural values, with visitors and hosts having mutually beneficial experiences and interactions (Wearing \& Neil, 2009). The concept of alternative tourism developed in the early 1980s and comprised activities and products that were perceived to be less damaging than mass tourism. This marked the beginning of a commitment to sustainability (Weaver, 2006).

Ecotourism is a type of alternative tourism and has been identified by many destinations as a less destructive tourism that aims to satisfy conservation and economic development goals (Fennell, 2015; Montaguti \& Mingotto, 2015). Ecotourism frequently occurs in national parks and other protected areas. Natural areas as tourism destinations are challenged to protect natural resources, while providing facilities and positive recreational experiences for visitors (Deng, Walker, \& Swinnerton, 2005; Knudsen \& Greer, 2008). It is essential that managers understand tourists' perspectives about the appropriate activities in national parks to enable the use of resources without misuse and ecological degradation (Morrison et al., 2019; Wright \& Rollins, 2002).

\footnotetext{
${ }^{*}$ Corresponding author.

E-mail address: sam.ghazvini@hotmail.com (S.A.M. Ghazvini)
} 
Sustainable tourism and ecotourism are analogous endeavours to connect rural development, economic growth and environmental protection. Ecotourism additionally provides novel experiences and educational opportunities for tourists while its performance and development should be compliant with environmental sensitivity and protection. Ecotourism in Malaysia began several decades ago, but there are still significant failures, with regard to upholding the principles of sustainability (Jaini, Anuar, \& Daim, 2012). Ecotourism should facilitate the goals of sustainable development, mainly due to its economic rationale in relation to its preservation goals (Fennell, 2015; Wildes, 1998).

Ecotourism is an important product in Malaysia because of its island environments, sandy beaches, clear waters and vast rainforests (Jaafar \& Maideen, 2012), although it is worth noting that not all national park tourism in the country is 'ecotourism'. Malaysia has attractive landscapes, majestic ecosystems, biological diversity and exclusive cultures. Malaysia is one of 17 so-called 'mega-diverse' countries that shelter $70 \%$ of Earth's species and are exceedingly bio-diverse. Sound planning can help maintain this diverse environment, but some hazards such as improper management, illegal logging, and poaching threaten the integrity of these priceless ecosystems and consequently diminish the potential for some regions to become ecotourism destinations (Abdullah, Weng, \& Som, 2011).

Malaysia is one of Southeast Asia's most visited countries and is concerned with ensuring that its industry follows the principles of sustainability (Novelli, Klatte, \& Dolezal, 2017). Some of the country's main barriers to ensuring sustainable development through ecotourism are inadequate ecological and environmental training, environmental insecurity, a shortage of suitable knowledge about ecotourism management, and a lack of political and public will to ensure ecosystem quality (Nair, 2008). Malaysia has a multi-cultural population and receives millions of foreign tourists each year.

Empirical studies on tourists' environmental values and perceptions of appropriate activities in national parks are scarce. Thus, a better understanding of people's thoughts about protected area use is needed. Such knowledge is important for national park managers and other decision makers to match policies with tourists' attitudes to maintain the integrity of park ecosystems and to implement the concept of 'use without abuse' inside protected areas (Floyd, 1999). This study hypothesises that there is a significant relationship between tourists' environmental concerns and their views of appropriate uses of national parks. It attempts to achieve the following objectives:

1) To examine the differences between domestic and international tourists' perspectives in Malaysia on appropriate uses of national parks.

2) To identify the extent of tourists' concerns with the environment.

3) To investigate the relationship between tourists' environmental concerns and their perceived appropriate uses of national parks.

\section{Conceptual development}

\subsection{The value-belief-norm theory}

This study is built upon a complex theory of pro-environmental behaviour known as the value-belief-norm theory (VBN). This concept was developed by Stern and his colleagues (Stern, 2000; Stern, Dietz, Abel, Guagnano, \& Kalof, 1999; Stern, Dietz, Kalof, \& Guag-nano, 1995) and rationalises the ethical facets of behaviour. The the-ory argues that pro-environmental behaviours are rooted in value ori-entations (egoistic, altruistic, biospheric), environmental beliefs (ecolog-ical worldview, awareness of consequences, the ascription of responsi-bility), and personal norms. Indeed, VBN is an amalgam of three con-tributing theories: the theory of Moral NormActivation or Norm-Acti-vation (Schwartz, 1973, 1977), the Universal Theory of Human Val-ues or Personal Values (Schwartz, 1992, 1994; Schwartz \& Bil sky, 1987), and the New Ecological Paradigm (Dunlap \& Van Liere, 1978; Dunlap, Van Liere, Mertig, \& Jones, 2000). All three of these theoretical structures have informed this study, the survey instrument and the analysis.

\subsubsection{Norm-Activation Theory}

Norm-Activation Theory proposes that pro-environmental activities happen consistently and are propelled by personal moral norms. Pro-environmental actions are stimulated in reaction to people's norms-people who consider that environmental challenges are perilous to the biosphere, other species and humankind. Considerable evidence in support of the theory's applicability to environmental problems has amassed from many case studies (e.g. Johansson, Rahm, \& Gyllin, 2013; López-Mosquera \& Sánchez, 2012; Schultz \& Zelezny, 1999; Steg, Dreijerink, \& Abrahamse, 2005; Stern, 2000; Stern et al., 1999; Thøgersen \& Ölander, 2002; Widegren, 1998).

\subsubsection{The Universal Theory of Human Values}

The Universal Theory of Human Values was developed by Schwartz (1992, 1994) and pursues the prevalent concept of values (Rokeach, 1968) as directional and crucial factors that determine viewpoints and actions. Many cross-cultural studies have referred to Schwartz's framework for human values, especially studies related to environmental issues. They have shown the efficacy of Schwartz's model for evaluating and classifying values among various cultures (De Groot \& Steg, 2007, 2008, 2010; Hansla, Gamble, Juliusson, \& Gärling, 2008; Oishi, Schimmack, Diener, \& Suh, 1998; Spini, 2003). A number of psychological studies concerning environmental attitudes have concentrated on values that are considered cognition factors of more particular beliefs, attitudes and behaviours (Olson \& Zanna, 1993).

\subsubsection{New Ecological Paradigm}

The New Ecological Paradigm was developed by Dunlap and his collaborators (Dunlap \& Van Liere, 1978; Dunlap et al., 2000) and holds that the growth of the environmental movement (conservation and green politics) is connected to the acquiescence of a new ecological paradigm. This worldview is broadly utilised as a social psychological measurement in environmental studies (Matsiori, 2020) and renders a person susceptible to developing very specific beliefs regarding adverse environmental issues (Stern et al., 1999). The new ecological paradigm is founded on an outlook that human behaviours have significant unfavourable impacts on delicate environments (Stern, Dietz, \& Guagnano, 1995).

\subsection{Environmental concerns}

In recent decades, conserving resources, especially energy, water and biodiversity, as well as the failure to maintain aesthetic values, have been a focus of research. Environmental problems generally exist everywhere and are diluted by time and space, while pollution and dangerous waste continue to be problematic in specific locations (Stern, Young, \& Druckman, 1992). The accelerated, nonstop use and degradation of natural resources is a salient concern for many people and their environment. Many attempts have been made to change people's negative environmental behaviours, and although some efforts have seen limited success (Fransson \& Garling, 1999; Ulman, 2018), many studies have shown that childhood education programs and effective policing in parks have been successful in mitigating people's negative environmental behaviours (Bergman, 2016; Blanchard \& Buchanan, 2011; Plumptre, 2019; Vimal, Gatiso, \& Mathevet, 2018).

Environmental concerns have been widely studied by examining the public worldview and normative beliefs about the environment (Dunlap et al., 2000; Shao, 2017), emotional connections to the natural world (Baur, Ries, \& Rosenberger, 2020; Mayer \& Frantz, 2004 
), anxiousness related to ecological hardships (Bradley \& Reser, 2017; Li \& Monroe, 2019; Schultz, Shriver, Tabanico, \& Khazian, 2004), and particular opinions related to environmental problems (Stern et al., 1995).

Dietz, Stern, and Guagnano (1998) propose that studies about environmental concerns should pay attention to two areas: how ecological concerns influence environmental behaviour and how socio-demographics influence environmental concerns. Environmental concerns are usually a result of personal appraisals of environmental challenges (Fransson \& Garling, 1999).

Several studies have ascertained that in general, people are worried about environmental issues because of their awareness of humankind's ecological impacts. These studies have focused on environmental concerns related to individuals (egoistic), other people (altruistic), and plants and animals (biospheric) (Hansla et al., 2008; Schultz, 2001; Schultz et al., 2004; Swami, Chamorro-Premuzic, Snelgar, \& Furnham, 2010; Verma, Chandra, \& Kumar, 2019).

\subsection{Appropriate uses of national parks}

The planet suffers from air pollution, desertification, water pollution, acute deforestation and global warming, all of which threaten environmental quality and are rooted in human attitudes and behaviours. Therefore, appropriate management and sound environmental planning are critical in managing protected area-based tourism (Ghazvini, Lim, \& Sarmento, 2016). Protected areas, especially national parks, encompass various attractions, including flora and fauna, natural scenery, cultural sites in some cases, and outdoor activities. The increasing range of tourism, commercial tour operations, visitations and recreational activities in protected areas is reflected in the continued growth of protected area-based tourism (Bello, Carr, \& Lovelock, 2016; Pickering, Rossi, Hernando, \& Barros, 2018).

Accommodating and educating visitors from different cultures is one aim of many national parks (Li, 2018). Understanding the viewpoints of different populations regarding appropriate activities in national parks plays an important role in decision making and maintaining ecological integrity (Rollins \& Robinson, 2002). With the growth of ecotourism, there is increasing pressure on protected areas to provide facilities, overnight accommodations, and different types of activities (Huang, Deng, Li, \& Zhong, 2008). Protected land managers encounter challenges, including human-wildlife conflicts, habitat loss and illegal hunting, which emanate largely from rapid population growth and poverty (Kideghesho, 2010).

Park managers face increased use and misuse of resources, even while they realize economic gains from tourism. Apart from illegal logging and poaching, the main threat to the ecological integrity of national parks is the expansion of tourist facilities and over-visitation. Nonetheless, by developing tourism activities, many national parks attempt to draw large numbers of tourists, sometimes sacrificing park environments in the process (Rollins \& Robinson, 2002; Swinnerton, 1999), although many examples exist in parks where conservation and visitor use co-exist harmoniously (e.g. Eagles, McCool, \& Haynes, 2002; Leung, Spenceley, Hvenegaard, \& Buckley, 2018).

People's support is necessary to achieve the conservation goals of national parks. One way of determining public support for national parks is to examine consumers' thinking about proper uses and activities. Providing facilities and services for recreational activities is essential to satisfy the needs of visitors and create enjoyable experiences. However, sometimes this threatens the ecological integrity of national parks (Deng et al., 2005; Tverijonaite, Ólafsdóttir, \& Thorsteinsson, 2018). Ecocentric tourists are more supportive of management actions that control access, activities and impacts. They are also more interested in experiencing local culture, nature and wilderness (Kaltenborn, Nyahongo, \& Kideghesho, 2011).

Most respondents in Borrie, Freimund and Davenport's (2002) study recognised national parks as places for nature protection rather than places for other purposes. Their study showed that certain people support a protection mandate over a use mandate at Yellowstone National Park. Huang et al. (2008) similarly found that many people place a higher priority on conservation than on physical development and recreational use. Participants who believe that environmental protection is a higher priority were more likely to support non-consumptive activities; fewer were likely to compromise protection for use. They suggested limiting the number of visitors and gradually phasing out inappropriate activities. Visitors expressed that appreciative or passive activities are more appropriate than consumptive activities. The negative impact of consumptive activities (e.g. hunting, fishing, etc.) is significantly greater than appreciative activities on the park environment. Huang et al.'s (2008) study found that some tourism and recreation services and facilities, and infrastructure were deemed inappropriate or less appropriate from visitors' perspectives.

Deng et al. (2005) compared Anglo-Canadian and Chinese-Canadian attitudes about appropriate uses of national parks and concluded that both groups' perceptions were similar regarding sport and visitor facilities. They differed, however, in their views of other features of suitable use. Anglo-Canadians supported more accommodations and service facilities; they also expressed less support for both non-consumptive and consumptive activities. According to this group, all non-consumptive activities were appropriate, while gambling and hunting were deemed inappropriate. This evidence suggests that different cultural groups may express different environmental concerns.

\section{Methods and study location}

This study adopted a quantitative research framework in which 400 paper questionnaires were distributed to every second visitor at the main entrance to Taman Negara in Malaysia. 'Taman Negara' means 'national park' in Malay and is also the name of the national park. From this number, 379 completed and useable questionnaires were collected, representing a remarkable response rate of 94.8 percent. A 5-point Likert scale was used, and participants were asked to indicate their level of agreement with each item from 1 (strongly disagree) to 5 (strongly agree). The questionnaire contained information derived from the literature regarding environmental concerns and appropriate sorts of activities within and uses of national parks (Deng et al., 2005; Dunlap et al., 2000; Huang et al., 2008), in connection with Value-Belief-Norm Theory, which derived from the principles spelled out in the Norm-Activation Theory, the Universal Theory of Human Values and the New Ecological paradigm. Participants were asked about their environmental concerns, their perceptions of appropriate park uses and their demographic information. The unit of analysis was divided into international tourists and domestic tourists. Taman Negara is the oldest and the first protected area in Malaysia, and its ecosystem is approximately 130 million years old. The park is home to one of the most complex and riches ecosystems on Earth ("Tourism Malaysia, 2014"). The park comprises a total area of $4343 \mathrm{Km}^{2}$ and is located in three states: Pahang, Kelantan and Terengganu (Fig. 1).

Participants were screened to determine if they were residents of the local area or visitors from further away. Of the 379 participants in this study, $53.8 \%$ were international tourists $(\mathrm{n}=204)$, and $46.2 \%$ were domestic tourists $(n=175)$. Most visitors were males $(64.9 \%, n=246)$, lived in urban areas $(72.3 \%, \mathrm{n}=274)$ and were between 20 and 50 years old $(88.1 \%, \mathrm{n}=334)$. Most international tourists came from developed countries (85.3\%), of which $79.9 \%$ of these were Europeans.

\subsection{Measurements}

Environmental concerns: This study utilised the New Ecological Paradigm (NEP) scale consisting of 15 items. Visitors were asked to indicate their agreement or disagreement regarding the 15 statements about the relationship between humans and the environment. The scale showed a reliability value of 0.71 . 


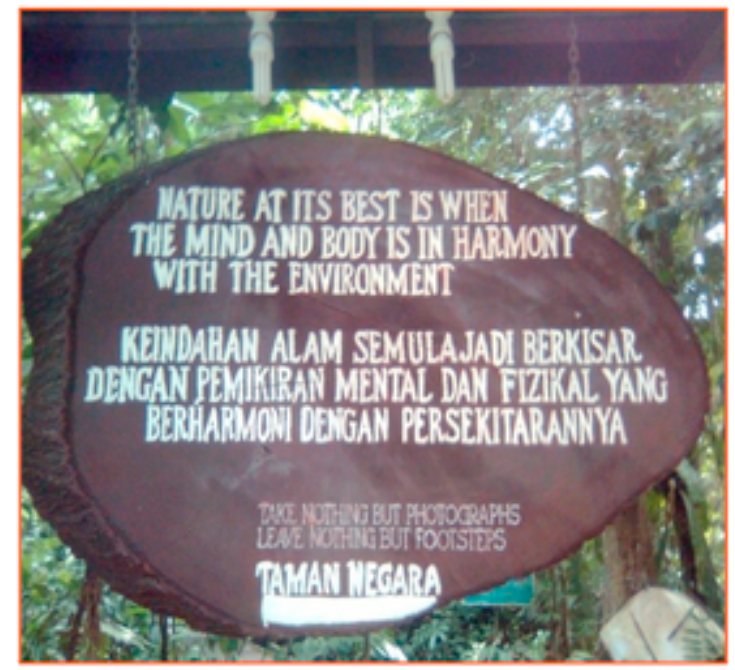

(a)

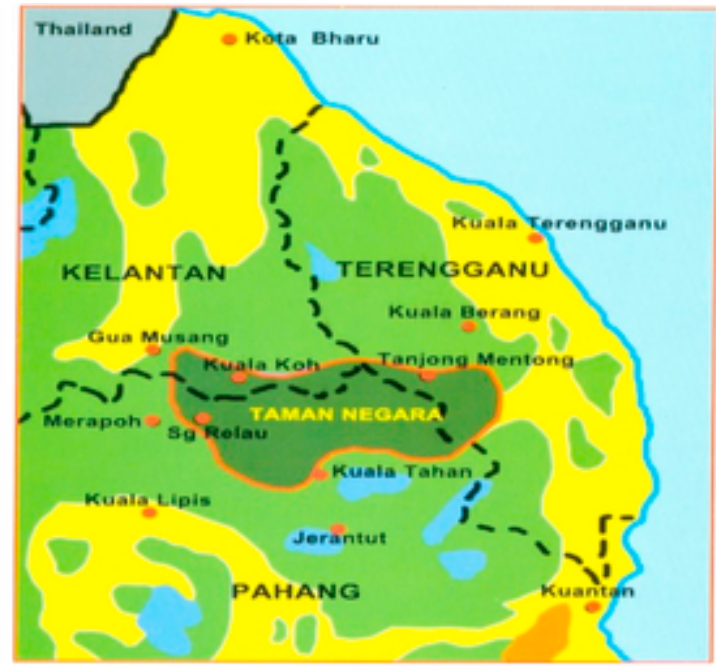

(b)

Fig. 1. (a) Motto; and (b) Location of Taman Negara and surrounding areas.

Appropriate uses of national parks: Thirty-seven items were listed to appraise the appropriateness or inappropriateness of existing accommodations, services, activities and facilities within national parks. Participants were asked to indicate how each item is environmentally appropriate or inappropriate. The reliability of the scale attained a value of 0.91 which displays high reliability (Hinton, McMurray, \& Brownlow, 2014).

\subsection{Data analysis}

This study employed the Statistical Package for Social Science (SPSS, version 21.0) to analyse the data. Several statistical analyses were utilised to meet the research objectives. We applied exploratory factor analysis and principal components method as an extraction technique with varimax rotation, which is pertinent to the orthogonal rotation approach (Tabachnick \& Fidell, 2012). In addition, the study used parallel analysis to confirm the number of factors obtained. Multivariate Analysis of Variance (MANOVA), particularly one-way MANOVA, was used to reveal the differences between domestic and international tourists concerning appropriate uses of national parks. A number of simple linear regressions were employed to analyse the relationship between participants' environmental concerns and their perceptions of appropriate activities and uses in national parks. The study also used an independent-samples t-test to determine the differences in environmental concerns between domestic and international tourists.

\section{Evaluation and results}

\subsection{Factor analysis}

Results of the factor analysis regarding the appropriate or inappropriate use of national parks, are shown in Table 1. An analysis of the total sample was carried out. Eight factors were extracted with eigenvalues greater than 1 . Item 23 "non-motorised boating" and item 32 "horse riding" loaded on factor 6 . Item 1 "tents/campgrounds" and item 35 "religious activities" were included in factors 7 and 8 respectively and did not load with other items. Item 24 "picnicking/barbequing" had a cross loading with factor 6 and 7.

Factors 6, 7 and 8 were excluded from further analysis in accordance with Pallant (2011) and Tabachnick and Fidell (2012), who suggest that factors with three or more loading items are preferred, and factors that contain only one or two items should not be interpreted. Subsequently, a parallel analysis was performed to verify the number
Table 1

Factor loadings and Cronbach's coefficient alphas for appropriate or inappropriate uses of national parks.

\begin{tabular}{|c|c|c|}
\hline Factors and related items & Loadings & $\begin{array}{l}\text { Cronbach's } \\
\text { Alpha }\end{array}$ \\
\hline Factor 1: Accommodation and service facilities & & 0.90 \\
\hline 2. Hotel/motel accommodation & 0.64 & \\
\hline 3. Residency/permanent homes & 0.54 & \\
\hline 8. Hospital/Medical services & 0.67 & \\
\hline 9. Restaurants or lounges & 0.77 & \\
\hline 10. Gas/Service stations & 0.72 & \\
\hline 11. Gift shops & 0.74 & \\
\hline 12. Visitor information/Interpretive centres & 0.53 & \\
\hline 13. School/Educational services & 0.53 & \\
\hline 14. Grocery stores & 0.77 & \\
\hline 15. Conference facilities & 0.59 & \\
\hline 16. Pavilions & 0.61 & \\
\hline 17. Shopping centres & 0.55 & \\
\hline Factor 2: Non-consumptive activities & & 0.82 \\
\hline 18. Mountain biking & 0.41 & \\
\hline 20. Jogging/Running/Walking & 0.80 & \\
\hline 21. Wildlife watching & 0.85 & \\
\hline 25. Hiking/Backpacking & 0.89 & \\
\hline 26. Taking pictures & 0.44 & \\
\hline 30. Caving & 0.48 & \\
\hline 31. Swimming/Sunbathing & 0.49 & \\
\hline 34. Rock-climbing/Mountaineering & 0.60 & \\
\hline Factor 3: Motorised activities & & 0.77 \\
\hline 19. Small aircraft flights & 0.53 & \\
\hline 29. Chair lifts/Cable cars/Sightseeing elevators & 0.66 & \\
\hline 36. Sightseeing by car & 0.73 & \\
\hline 37. Power boating & 0.74 & \\
\hline Factor 4: Sport/Recreation facilities & & 0.83 \\
\hline 4. Children's playgrounds & 0.75 & \\
\hline 5. Sport fields (soccer, basketball, etc.) & 0.76 & \\
\hline 6. Golf courses & 0.70 & \\
\hline 7. Skiing area & 0.63 & \\
\hline 22. Dancing/karaoke lounges & 0.66 & \\
\hline Factor 5: Consumptive activities & & 0.60 \\
\hline $\begin{array}{l}\text { 27. Gathering natural edible products (fruit, berries, } \\
\text { mushrooms, fern fiddleheads, etc) }\end{array}$ & 0.70 & \\
\hline 28. Fishing & 0.76 & \\
\hline 33. Hunting & 0.52 & \\
\hline
\end{tabular}


of factors that should be retained. The results supported keeping five factors (see Table 2).

In accordance with Table 2, five eigenvalues from the principle component analysis are greater than the criterion values from the parallel analysis. Therefore, parallel analysis confirms the extraction of five factors for measuring appropriate national park uses. Moreover, these five factors cumulatively explained $52.5 \%$ of the variance.

\subsection{Differences in perceptions of appropriate national park uses among international and domestic tourists}

The means and standard deviations from the five sub-scales of appropriate uses of national parks are displayed in Table 3. Accordingly, domestic tourists displayed a higher mean score than their international counterparts, while only consumptive activities had a greater mean score for the foreigners compared to domestic tourists (2.76 vs. 2.74). Non-consumptive activities showed the highest mean scores for both international (3.88 out of 5 , with 5 signifying that a use or facility is entirely appropriate and 1 indicating it is entirely inappropriate) and domestic ( 4.06 out of 5 ) tourists.

Following up on these descriptive findings, a one-way multivariate analysis of variance (MANOVA) was performed to prove statistical differences in the perceptions of the two groups related to appropriate activities and uses in national parks (see Table 4). Five dependent variables were employed: accommodation and service facilities, non-consumptive activities, motorised activities, sport/recreation facilities and consumptive activities. Nationality was the independent variable, comprised of international $(n=204)$ and domestic $(n=175)$. Preliminary assumption testing was carried out to verify linearity, outliers, homogeneity of variance-covariance matrices, normality and multicollinearity. The assumption of homogeneity of variance-covariance matrices was not met based on Box's $M$ test indication, $F(15,544402)=4.47$, $p<0.001$. However, violation of normality and equality of variance-covariance matrices with large sample sizes and groups with approximately equal size have minimal impact (largest group $\div$ smallest group < 1.5) (Hair, Black, Babin, \& Anderson, 2010). Table 4

Table 2

Comparison of parallel analysis' criterion values and eigenvalues from PCA.

\begin{tabular}{llllll}
\hline Factors & $\begin{array}{l}\text { Actual } \\
\text { eigenvalue } \\
\text { From PCA }\end{array}$ & $\begin{array}{l}\text { Criterion } \\
\text { value from } \\
\text { Parallel } \\
\text { analysis }\end{array}$ & Decision & $\begin{array}{l}\text { Percent } \\
\text { of } \\
\text { variance }\end{array}$ & $\begin{array}{l}\text { Cumulative } \\
\text { percent }\end{array}$ \\
\hline 1 & 9.055 & 1.6513 & Accepted & 24.5 & 24.5 \\
2 & 4.127 & 1.5637 & Accepted & 11.1 & 35.6 \\
3 & 2.887 & 1.5041 & Accepted & 7.8 & 43.4 \\
4 & 1.918 & 1.4551 & Accepted & 5.2 & 48.6 \\
5 & 1.453 & 1.4091 & Accepted & 3.9 & 52.5 \\
6 & 1.299 & 1.3698 & Rejected & - & - \\
7 & 1.145 & 1.3320 & Rejected & - & - \\
8 & 1.063 & 1.2934 & Rejected & - & - \\
\hline
\end{tabular}

Table 3

Means and standard deviations of five sub-scales of appropriate national park uses.

\begin{tabular}{lllll}
\hline Measurements & \multicolumn{2}{l}{ International } & \multicolumn{2}{l}{ Domestic } \\
\hline & M & SD & M & SD \\
\hline Accommodation and service facilities & 2.73 & 0.61 & 3.55 & 0.86 \\
Non-consumptive activities & 3.88 & 0.54 & 4.06 & 0.64 \\
Motorised activities & 2.06 & 0.76 & 2.69 & 1.02 \\
Sport/recreation facilities & 2.21 & 0.89 & 2.51 & 1.05 \\
Consumptive activities & 2.76 & 0.92 & 2.74 & 0.93 \\
\hline
\end{tabular}

Table 4

Multivariate analysis of variance for appropriate uses of national parks.

\begin{tabular}{|c|c|c|c|c|c|c|}
\hline Effects & Value & $F$ & $d f$ & $\begin{array}{l}\text { Error } \\
d f\end{array}$ & $P$ & Partialn $^{2}$ \\
\hline Wilks' Lambda & 0.72 & 28.32 & 5 & 373 & 0.000 & 0.27 \\
\hline $\begin{array}{l}\text { Accommodation and } \\
\text { service facilities }\end{array}$ & & 116.89 & 1 & 377 & 0.000 & 0.24 \\
\hline $\begin{array}{l}\text { Non-consumptive } \\
\text { activities }\end{array}$ & & 7.96 & 1 & 377 & 0.005 & 0.02 \\
\hline Motorised activities & & 46.55 & 1 & 377 & 0.000 & 0.11 \\
\hline $\begin{array}{l}\text { Sport/recreation } \\
\text { facilities }\end{array}$ & & 8.66 & 1 & 377 & 0.003 & 0.02 \\
\hline Consumptive activities & & 0.02 & 1 & 377 & 0.874 & 0.00 \\
\hline
\end{tabular}

shows the results of the multivariate analysis of variance for appropriate national park uses.

As the table shows, there is a significant difference in combined dependent variables across international and domestic respondents, $F$ $(5,373)=28.32, \quad p<0.001$; Wilks' Lambda $=0.72$; partial eta squared $=0.27$. After applying the Bonferroni adjusted alpha level of 0.01 in view of dependent variables separately, four variables attained significant differences. Accommodation and service facilities, $F$ (1, $377)=116.89, p<0.001$; partial eta squared $=0.24$, non-consumptive activities, $F(1,377)=7.96, \quad p=0.005$; partial eta squared $=0.02$, motorised activities, $F(1,377)=46.55, p<0.001$; partial eta squared $=0.11$ and sport/recreation facilities, $F(1$, $377)=8.66, p=0.003$; partial eta squared $=0.02$. Consumptive activities were the only variable that was not significantly affected, F (1, $377)=0.02, \mathrm{p}=0.874$; partial eta squared $=0.00$.

\subsection{Differences in international and domestic tourists' environmental concerns}

This study aimed to evaluate tourists' environmental concerns using the revised new environmental paradigm (NEP), including 15 items as a unidimensional measurement. Seven even-numbered variables were reverse coded to assure that higher scores indicate pro-ecological worldviews. In this case, it can be concluded that lower scores on items indicate an anthropocentric viewpoint, while higher scores indicate a more biocentric viewpoint. The mean scores of international and domestic tourists' responses in relation to the environmental concerns scale demonstrate that international tourists possessed higher mean scores for environmental concerns (3.62 out of 5) than domestic tourists (3.33 out of 5). This indicates that foreign tourists have a higher proclivity for pro-ecological worldviews than domestic tourists do. Drawing upon the descriptive analysis, an independent-samples t-test was conducted to confirm significant differences in environmental concerns between international and domestic visitors. The marginal mean score for foreign tourists $(\mathrm{M}=54.38, \mathrm{SD}=6.61$, SE Mean $=0.46)$ was greater than the mean score for domestic tourists $(M=49.99, S D=4.13, S E$ Mean $=0.31$ ).

In reference to preliminary assumptions of normality and the equality of variances, the results of the Levene's test showed that variances in environmental concerns were not equal (sig. value $<0.001$ ). Therefore, information related to the row of "equal variances not assumed" were used for comparison between groups. Table 5 demonstrates the results of the independent-samples test.

The eta squared is calculated based on the following equation:

$$
\begin{aligned}
& \text { Eta squared }\left(\eta^{2}\right)=\frac{t^{2}}{t^{2}+\left(\mathrm{N}_{1}+\mathrm{N}_{2}-2\right)} \\
& \left(\eta^{2}\right)=\frac{7.85^{2}}{7.85^{2}+(204+175-2)}=0.14
\end{aligned}
$$


Table 5

Result of the independent-samples test.

T-Test for equality of means

\begin{tabular}{lllllll}
\hline & & & & & \multicolumn{3}{l}{$\begin{array}{l}\text { 95\% confidence } \\
\text { interval of the } \\
\text { difference }\end{array}$} \\
& $\mathrm{t}$ & $\mathrm{df}$ & Sig. & Difference & Lower & Upper \\
\hline $\begin{array}{l}\text { Environmental } \\
\text { concerns }\end{array}$ & 7.85 & 346 & 0.000 & 4.38 & 3.28 & 5.48 \\
\hline
\end{tabular}

According to Cohen criteria, the following are generally accepted: eta squared with a value of $0.01=$ small effect, $0.06=$ moderate effect, and $0.14=$ large effect. Consequently, the effect size of 0.14 is large and it can be noted that $14 \%$ of the variance in environmental concerns is explained by tourists being international or domestic.

The result of the independent-samples t-test to compare environmental concerns scores for domestic and foreign visitors revealed a significant difference in scores with a higher level of environmental concerns for international $(M=54.38, S D=6.61)$ visitors than for domestic visitors $(M=49.99, S D=4.13) ; t(346)=7.85, p<0.001$ (two-tailed).

\subsection{The relationship between environmental concerns and appropriate national park uses}

A preliminary test of the Pearson product-moment correlation coefficient revealed that there is no significant correlation between people's environmental concerns and approval of non-consumptive activities in national parks $(p=0.876)$. The researchers presumed this was owing to the statistical artefact. Therefore, four simple linear regression analyses were conducted to investigate the relationship between environmental concerns as a predictor variable and appropriateness of accommodation and service facilities, motorised activities, sport/recreation facilities and consumptive activities within national parks as criteria variables (see Table 6).

As Table 6 illustrates, the results disclosed that environmental concerns as an explanatory variable contributes to explaining tourists' perceptions of the appropriateness of accommodation and service facilities, motorised activities, sport/recreation facilities, and consumptive activities in national parks with explanations $17,16,11$, and $9 \%$ of the variance, respectively.

Table 6

Results of simple linear regression analysis on environmental concerns (EN) and sub-scales of appropriate national park uses.

\begin{tabular}{lrrrr}
\hline Predictors & $\mathrm{B}$ & $\mathrm{SE}$ & $\beta$ & $\mathrm{R}^{2}$ \\
\hline \multicolumn{2}{l}{ Accommodation and Service } & Facilities & & \\
Constant & 73.10 & 4.16 & & \\
EN & -0.68 & 0.08 & $-0.41^{* * *}$ & 0.17 \\
Motorised Activities & 22.61 & 1.56 & & \\
Constant & -0.25 & 0.03 & $-0.40^{* * *}$ & 0.16 \\
EN & 25.72 & 2.09 & & \\
Sport/Recreation Facilities & -0.27 & 0.04 & $-0.33^{* * *}$ & 0.11 \\
Constant & 15.49 & 1.19 & & \\
EN & -0.14 & 0.02 & $-0.30^{* * *}$ & 0.09 \\
Consumptive Activities & & \\
Constant & & & \\
EN &
\end{tabular}

Note: $* * * p<0.001$.

\section{Discussion}

The first objective of this study was to understand the differences between domestic and international tourists' perspectives on appropriate uses of a national park. Thirty-seven items concerning accommodations, facilities, services, and activities within national parks were classified into four categories based on mean scores. Items with mean scores less than 2 are considered highly inappropriate, between 2 and 2.99 moderately inappropriate, 3-3.99 moderately appropriate, and 4 and greater highly appropriate.

On the whole, both groups of tourists judged the majority of non-consumptive activities, or so-called appreciative or passive activities, as highly appropriate (e.g. taking pictures, caving, hiking/backpacking, jogging/running/walking, wildlife watching, rock climbing/ mountaineering), which is consistent with earlier findings in various locations (Huang et al., 2008; Littlejohn, 2000; Miller, Dickinson, \& Pearlman-Houghie, 2001). Appreciative activities have comparatively negligible negative environmental impacts in national parks, compared to sport/recreation facilities, consumptive activities, motorised activities, and accommodation and service facilities. Domestic tourists recorded "hospital/medical services", "school/educational services", "caving", and "rock climbing/mountaineering" as highly appropriate items, while international counterparts viewed these as moderately appropriate items. The category of "hospital/medical services" is unfortunately broad. In retrospect, this should have been divided further in the original survey, as most visitors, we believe, would want to know that a certain level of medical care is available within the park.

Most uses were regarded as moderately appropriate by both groups. Domestic tourists considered seven items of accommodation and service facilities (hotel/motel accommodation, restaurants or lounges, gas/service stations, gift shops, grocery stores, conference facilities, pavilions), three items of non-consumptive activities (mountain biking, swimming/ sunbathing, non-motorised boating), two items of consumptive activities (fishing, gathering natural edible products) and children's playgrounds from sport/recreation facilities as moderately appropriate items. On the other hand, international tourists regarded 4 items related to accommodation and services facilities (hotel/motel accommodation, restaurants or lounges, hospital/medical services, school/educational services), two items of consumptive activities (gathering natural edible products, fishing), four items of non-consumptive activities (caving, mountain biking, swimming/sunbathing, rock climbing/mountaineering), and children's playgrounds as moderately appropriate activities and uses within national parks.

It is noteworthy that both groups similarly assigned some items as moderately appropriate but at the same time, domestic tourists discerned "gas/service stations", "gift shops", "grocery stores", "conference facilities", and "pavilions" as moderately appropriate items; on the opposite side, international tourists categorized these items as moderately inappropriate.

Interestingly, both groups perceived fishing and gathering natural edible products (e.g. fruits, berries, mushrooms, fern fiddleheads), which are usually considered consumptive activities, as moderately appropriate activities. This finding is in accordance with the results of studies by Huang et al. (2008) and Anderson, Blahna, and Chavez (2000), which examined commercial and leisure foraging.

Some studies have suggested that different cultural groups have different values related to consumptive activities, such as fishing. Toth and Brown (1997) and Campbell (1989) studied different cultural groups' perceptions and experiences with fishing and found that people from various cultural backgrounds view fishing differently. Southeast Asian migrants and African-Americans saw fishing as an important part of their sustenance, as did many Anglo-Americans, although the latter fished more for entertainment and leisure (West, Fly, Larkin, \& Marans, 1992). Our findings are consistent with abovementioned studies in that people have a propensity to value leisure activities that simultaneously provide sustenance and leisure. Consequently, fish- 
ing and gathering natural edible products may be conceived as appropriate uses of national park resources.

In terms of inappropriate uses and activities, motorised pursuits (e.g. small aircraft flights, sightseeing by car, power boating, chair lifts/cable cars), the majority of items associated with sport/recreation facilities (e.g. sport fields, golf courses, ski areas, dancing/karaoke lounges), and two items of accommodation and services facilities (e.g. residency/permanent homes, shopping centres) were viewed as moderately inappropriate by domestic tourists. International tourists considered several uses related to lodging and services (e.g. gas/service stations, gift shops, conference facilities, pavilions, grocery stores), some motorised activities (e.g. chair lifts/cable cars/sightseeing elevators, small aircraft flights) and also athletic fields as moderately inappropriate uses. These types of activities and services provoke disagreements between practitioners, policymakers, and academics regarding the appropriateness of human activities in protected areas.

According to Nair (2008), golf courses in Malaysia have not been controversial or created significant problems, but he warns that they should not damage the environment to offer short-term advantages for only a few people in eco-sensitive areas. Thus, it can be concluded that since golf courses are not known to be problematic in Malaysia, domestic tourists perceive them as only moderately inappropriate in national parks, compared to international tourists who view them as highly inappropriate.

There was a consensus between both groups regarding the inappropriateness of hunting, which is consistent with the findings of Deng et al. (2005). While domestic visitors valued hunting as the only highly inappropriate activity, international participants regarded two items related to accommodations and service facilities (residency/permanent homes, shopping centres), some sport/recreation facilities (golf courses, skiing area, dancing/karaoke lounges), motorised activities (sightseeing by car, power boating), and hunting as being highly inappropriate. It is noteworthy that "residency/permanent homes" and "hunting" were identified as the least appropriate activities by international and domestic tourists, respectively. This outlook may be affected by the fact that Malaysia continues to experience an illegal wildlife trade, poaching and unsustainable hunting. The road network has expanded, which has facilitated accessibility for hunters equipped with shotguns, searchlights and freezers, in forests that were previously inaccessible ("WildlifeConservation Society, 2013). The Malaysian government and NGOs have tried to engage members of society in conserving protected areas, including fauna. They publicise the latest changes in hunting rules and regulations, and wildlife legislation along with conservation messages. In addition, Wildlife Crime Hotline was established to help the public report poaching and illegal wildlife trade ("Malaysian Conservation Alliance for Tigers, 2012").

Among the five sub-scales determined from the factor analysis, domestic tourists, compared to international tourists, had higher mean scores for the four sub-scales of accommodation and service facilities, non-consumptive activities, motorised activities and sport/recreation facilities, and a slightly lower score for the remaining sub-scale: consumptive activities. Thus, domestic tourists, compared to international tourists, are more likely to see the first four national park uses as appropriate, whereas they are less likely to perceive consumptive activities as appropriate. Non-consumptive activities obtained the highest mean scores by both tourist groups.

Differences between national and international tourists were supported by the MANOVA test, which showed that domestic tourists demonstrated statistically significant differences from their foreign counterparts in four out of five national park uses. However, the minor difference regarding consumptive activities was not statistically significant.

The second objective of the study was to identify the extent of tourists' environmental concerns. Domestic and international participants showed both similarities and differences in this regard. Both groups identically voiced strong agreement with the following two statements: "when humans interfere with nature, it often produces disastrous consequences" and "plants and animals have as much right as humans to exist".

Despite the fact that the domestic participants did not 'strongly disagree' or 'mildly disagree' with any items or statements, the foreign tourists assigned five statements with these categories. These statements were: "humans have the right to modify the natural environment to suit their needs", "the balance of nature is strong enough to cope with the impacts of modern industrial nations", "the so-called ecological crisis facing humankind has been greatly exaggerated", "humans were meant to rule over the rest of nature", and "humans will eventually learn enough about how nature works to be able to control it". The lowest mean score was assigned to the statement, "humans were meant to rule over the rest of nature" for the domestic tourists, and "the balance of nature is strong enough to cope with the impacts of modern industrial nations" for international tourists.

Concerning the mean scores, domestic and international tourists were comparatively concerned about humans mistreating the environment, the plenitude of natural resources as long as they are sustainably used, the limitations of the earth's resources, and the fragility of nature's balance and that it might easily be upset. Statistical tests revealed that whether someone was a domestic or a foreign tourist significantly affected their environmental concerns; international visitors indicated deeper concerns for the environment than the Malaysians did.

A series of simple linear regressions assessed the relationship between tourists' environmental concerns and their perceptions of appropriate uses and activities in national parks. The results revealed that environmental concerns are significantly related to lodging and service facilities in national parks $\left(R^{2}=0.165\right.$, Adj. $R^{2}=0.167, \mathrm{~F}=74.72$, $\mathrm{p}<0.001$ ). In addition, environmental concerns negatively influence tourists' perceptions of appropriateness of accommodation and service facilities $(\beta=-0.41, p<0.001)$. The findings also indicate a statistically significant association between environmental concerns and motorised activities $\left(R^{2}=0.162\right.$, Adj. $\left.R^{2}=0.160, \mathrm{~F}=72.78, p<0.001\right)$. Tourists' perceptions of the appropriateness of motorised activities inside the national park are negatively influenced by their environmental concerns $(\beta=-0.40, p<0.001)$. The results also showed a statistically significant relationship between environmental concerns and sport/recreation facilities $\left(R^{2}=0.107\right.$, Adj. $R^{2}=0.105, \mathrm{~F}=45.40$, $p<0.001$ ), and environmental concerns have a negative effect on tourists' perceptions of the suitability of sport/recreation facilities within national parks ( $\beta=-0.33, p<0.001)$. A statistically significant association was also found between environmental concerns and consumptive activities $\left(R^{2}=0.091\right.$, Adj. $\left.R^{2}=0.088, \mathrm{~F}=37.53, p<0.001\right)$, and a negative influence of tourists' environmental concerns on their perceptions of consumptive activities $(\beta=-0.30, p<0.001)$ is evident.

\section{Conclusions}

This study was conducted among domestic and international tourists, who were visiting Taman Negara, Malaysia. Both groups considered some consumptive activities, lodging and other service facilities to be moderately appropriate in national parks, although they differed in their views of the appropriateness of other sorts of services and activities. Negative associations were found between tourists' environmental concerns and their perceptions of appropriate facilities and activities in national parks, which also reflect the findings of Ghazvini, Timothy, Sarmento, and Lim (2018) that environmental concerns mediate the relationship between value orientations and perceptions of appropriate national park uses.

Overall, it appears that domestic visitors are less concerned about the environment than international tourists are. This may derive from a lack of awareness of environmental problems in general or other differences, such as differing education levels, income and global awareness. In much of the developed world, there is a growing environmental ethos that begins in childhood through formal school curricula and ex- 
tracurricular activities, such as scouting, youth camps and nature-oriented programs, which aim to instill a sense of environmental stewardship (Schwartz et al., 2018). For many residents of Europe, North America, Australia and New Zealand, for example, ecological concerns are an integral part of growing up, and many schools utilize global standards (e.g. IUCN) to develop environmental education programs (Goodall, 2018; Reid, 2018). Although environmental education is becoming increasingly important in school curricula in a few developing countries (see Grúňová, Brandlová, Svitálek, \& Hejcmanová, 2017; Rakotomamonjy, Jones, Razafimanahaka, Ramamonjisoa, \& Williams, 2015), it lags behind the situation in most developed countries.

Law enforcement within national parks and other protected areas also varies from region to region. In many parts of the world, illegal or undesirable activities in national parks are well addressed through legislation, and the use of police powers to ensure that visitors conform to park policies and environmental protection laws are an effective way of mitigating bad behaviours (Hedemann-Robinson, 2015; Nurse, 2015). In the developed world, it is widely known and accepted that inappropriate behaviours and activities are not tolerated in national parks and that laws are strictly enforced.

In many less-developed parts of the world, however, policing in national parks is substandard, and in some cases non-existent (Gandiwa, Heitkönig, Lokhorst, Prins, \& Leeuwis, 2013; Moreto \& Lemieux, 2015). This sometimes reflects conditions of extreme poverty where local residents illegally hunt or poach, log or collect plant materials in parks and protected areas to survive. In extreme cases, law enforcement officers accept payment to look away from these situations. This paper, however, deals with tourists, not local residents. Although illegal activities do not seem to be a salient problem in Taman Negara (Ibrahim \& Hassan, 2011; Rasyikah, Sulaiman, Bakar, \& Ab Rahman, 2013), a general lack of law enforcement in protected areas in developing countries may mold people's perceptions of bad (unacceptable) or good (acceptable) behaviours and uses of national park lands, which can influence their views and behaviours when they travel.

Given these conditions of environmental values and park policing, it is not surprising that some of the views and priorities of international tourists and domestic tourists differed in this study. Different societies are conditioned differently by prevalent environmental education emphases and general knowledge of policing practices. Park authorities might consider playing a stronger role in helping domestic visitors understand environmental problems with an emphasis on their consequences for humankind.

People's environmental values and behaviours are difficult to influence once they reach adulthood. Nonetheless, there is considerable room for early childhood and youth education, which Malaysia's national park managers could engage in to help instill values early in life that parallel the values of the park and international conservation institutions. Likewise, national parks commonly recruit visitors who have compatible environmental attitudes, and they use police powers to ensure that visitors with incompatible values are not permitted to express those views through discordant behaviours, such as hunting, logging and plant removal, or supporting large-scale infrastructure development within park boundaries.

The managers of Taman Negara and other parks in Malaysia can learn valuable lessons from global examples and ensure that environmental laws are well enforced and work towards conservation values being integrated into national and local school curricula. The views of the international tourists revealed in this study are much closer to the IUCN criteria for parks and protected areas than their domestic counterparts. This study did not examine the extent to which Taman Negara adheres to the IUCN mandates of national parks, which are restrictive in the types of recreational and tourism activities allowed. Nonetheless, given that this study reveals different levels of tourists' acceptance of park activities and services, some of which are less ecologically sensi- tive than others, the park's managers should continue to align their policies and practices with the IUCN's directives to ensure that any activities and developments within the park remain conservation oriented rather than consumption driven.

This study has some important limitations. For instance, its focus was tourists visiting Taman Negara. Consequently, the results were attained from tourists only, without consideration of the views of local community users. As noted above, their views might be entirely different from those of domestic and foreign tourists. In addition, most participants in the study were urban residents with reasonably high levels of education, which might have influenced their perceptions. Likewise, the participants in this study were asked about several factors and items that do not necessarily exist in Taman Negara, because our goal was to understand park visitors' general perceptions about appropriate activities, not necessarily only those in the park where the survey was completed. Despite these weaknesses, this research has important implications for managers and regional decision makers who oversee national parks and other protected areas.

To further the principles of sustainable tourism and ecotourism, it is crucial that park managers understand visitors' values, environmental concerns and perceptions of appropriate uses of protected areas. National parks can provide educational opportunities and entertaining experiences, as well as satisfy people's recreational needs if tourism within them is planned properly and treated as an 'alternative' to mass tourism to empower communities, protect environments and provide satisfying human encounters with nature.

\section{Acknowledgements}

The research in this paper derives from master's thesis of the first author, which was undertaken at Universiti Teknologi MARA (UiTM), Malaysia. The authors wish to express their gratitude for the support of Dr. Lim Lay Kian, UiTM university, and its faculty of hotel and tourism management and staff. We also appreciate all constructive comments and advice from the editor and anonymous reviewers.

\section{References}

Abdullah, A R, Weng, C N, \& Som, A P M (2011). The potentials and perils of ecotourism in belum temengor forest complex. World Applied Sciences Journal, 12(12), 1-9.

Anderson, J A, Blahna, D J, \& Chavez, D J (2000). Fern gathering on the san bernardino national forest: Cultural versus commercial values among Korean and Japanese participants. Society \& Natural Resources, 13, 747-762.

Baur, J W R, Ries, P, \& Rosenberger, R S (2020). A relationship between emotional connection to nature and attutides about urban forest management. Urban Ecosystems, 23, 187-197.

Bello, F G, Carr, N, \& Lovelock, B (2016). Community participation framework for protected area-based tourism planning. Tourism Planning \& Development, 13(4), 469-485.

Bergman, B G (2016). Assessing impacts of locally designed environmental education projects on students' environmental attitudes, awareness, and intention to act. Environmental Education Research, 22(4), 480-503.

Blanchard, P B, \& Buchanan, T K (2011). Environmental stewardship in early childhood. Childhood Education, 87(4), 232-238.

Borrie, W T, Freimund, W A, \& Davenport, M A (2002). Winter visitors to Yellowstone National Park: Their value orientations and support for management actions. Human Ecology Review, 9(2), 41-48.

Bradley, G L, \& Reser, J P (2017). Adaptation processes in the context of climate change: A social and environmental psychology perspective. Journal of Bioeconomics, 19(1), 29-51.

Campbell, M B (1989). Fishing lore: The construction of the "sportsman". Annals of Tourism Research, 16(1), 76-88.

Carmi, N, Arnon, S, \& Orion, N (2015). Transforming environmental knowledge into behavior: The mediating role of environmental emotions. The Journal of Environmental Education, 46(3), 183-201.

De Groot, J I M, \& Steg, L (2007). Value orientations and environmental beliefs in five countries: Validity of an instrument to measure egoistic, altruistic and biospheric value orientations. Journal of Cross-Cultural Psychology, 38(3), 318-332.

De Groot, J I M, \& Steg, L (2008). Value orientations to explain beliefs related to environmental significant behavior: How to measure egoistic, altruistic, and biospheric value orientations. Environment and Behavior, 40(3), 330-354. 
De Groot, J I M, \& Steg, L (2010). Relationships between value orientations, self-determined motivational types and pro-environmental behavioural intentions. Journal of Environmental Psychology, 30, 368-378.

Deng, J, Walker, G J, \& Swinnerton, G (2005). A comparison of attitudes toward national park appropriate use between Chinese in Canada and Anglo-Canadians. World Leisure Journal, 47(3), 28-41.

Dietz, T, Stern, P C, \& Guagnano, G A (1998). Social structural and social psychological bases of environmental concern. Environment and Behavior, 30, 450-471.

Dunlap, R E, \& Van Liere, K D (1978). The new environmental paradigm. The Journal of Environmental Education, 9, 10-19.

Dunlap, R E, Van Liere, K D, Mertig, A G, \& Jones, R E (2000). Measuring endorsement of the new ecological paradigm: A revised NEP. Journal of Social Issues, 56(3), 425-442.

Eagles, P F J, McCool, S F, \& Haynes, C (2002). Sustainable Tourism in Protected Areas: Guidelines for Planning and Management. Gland, Switzerland: IUCN.

Fennell, D A (2015). Ecotourism (4th ed.). London: Routledge.

Floyd, M (1999). Race, ethnicity and use of the national park system. NPS Social Science Research Review, 1(2), 1-24.

Fransson, N, \& Garling, T (1999). Environmental concern: Conceptual definitions, measurement methods, and research findings. Journal of Environmental Psychology, 19, 369-382.

Gandiwa, E, Heitkönig, I M, Lokhorst, A M, Prins, H H, \& Leeuwis, C (2013). Illegal hunting and law enforcement during a period of economic decline in Zimbabwe: A case study of northern gonarezhou national park and adjacent areas. Journal for Nature Conservation, 21(3), 133-142.

Ghazvini, S A M, Lim, L K, \& Sarmento, J (2016). How important are value orientations to environmental concern? A comparison of national and international tourists in Malaysia. African and Asian Studies, 15(2-3), 265-288.

Ghazvini, S A M, Timothy, D J, Sarmento, J, \& Lim, L K (2018). Tourists' values and perceived appropriate uses of national parks. Tourism Analysis, 23(4), 445-459.

Goodall, S (2018). Developing Environmental Education in the Curriculum. London: Routledge.

Grúňová, M, Brandlová, K, Svitálek, J, \& Hejcmanová, P (2017). Environmental education supports conservation action by increasing the immediate and long-term environmental knowledge of children in West Africa. Applied Environmental Education and Communication, 16(1), 3-16.

Hair, J F, Black, W C, Babin, B J, \& Anderson, R E (2010). Multivariate Data Analysis (7th ed.). Harlow: Pearson.

Hansla, A, Gamble, A, Juliusson, A, \& Gärling, T (2008). The relationships between awareness of consequences, environmental concern, and value orientations. Journal of Environmental Psychology, 28, 1-9.

Hedemann-Robinson, M (2015). Enforcement of European Union Environmental Law: Legal Issues and Challenges. London: Routledge.

Hinton, P R, McMurray, I, \& Brownlow, C (2014). SPSS Explained (2nd ed.). London: Routledge.

Huang, Y, Deng, J, Li, J, \& Zhong, Y (2008). Visitors' attitudes towards China's national forest park policy, roles and functions, and appropriate use. Journal of Sustainable Tourism, 16(1), 63-84.

Ibrahim, Y, \& Hassan, M S (2011). Tourism management at taman Negara (national park), Pahang, Malaysia: Conflict and synergy. Journal of Ritsumeikan Social Sciences and Humanities, 3, 109-122.

Jaafar, M, \& Maideen, S A (2012). Ecotourism-related products and activities, and the economic sustainability of small and medium island chalets. Tourism Management, 33, 683-691.

Jaini, N, Anuar, A N A, \& Daim, M S (2012). The practice of sustainable tourism in ecotourism sites among ecotourism providers. Asian Social Science, 8(4), 175-179.

Johansson, M, Rahm, J, \& Gyllin, M (2013). Landowners' participation in biodiversity conservation examined through the value-belief-norm theory. Landscape Research, 38(3), 295-311.

Kaltenborn, B P, Nyahongo, J W, \& Kideghesho, J R (2011). The attitudes of tourists towards the environmental, social and managerial attributes of Serengeti National Park, Tanzania. Tropical Conservation Science, 4(2), 132-148.

Kideghesho, J R (2010). "Serengeti shall not die": Transforming an ambition into a reality. Tropical Conservation Science, 3(3), 228-248.

Knudsen, D C, \& Greer, C E (2008). Heritage tourism, heritage landscape, and wilderness preservation: The case of National Park Thy. Journal of Heritage Tourism, 3(1), $18-35$.

Leung, Y-F, Spenceley, A, Hvenegaard, G, \& Buckley, R (2018). Tourism and Visitor Management in Protected Areas: Guidelines for Sustainability. Gland, Switzerland: IUCN.

Li, C L (2018). Outdoor recreation in a Taiwanese national park: A Hakka ethnic group study. Journal of Outdoor Recreation and Tourism, 22, 37-45.

Li, C J, \& Monroe, M C (2019). Exploring the essential psychological factors in fostering hope concerning climate change. Environmental Education Research, 25(6), 936-954.

Littlejohn, M (2000). Visitor opinions and park resources. Park Science, 20(1), 1-4.

López-Mosquera, N, \& Sánchez, M (2012). Theory of Planned Behavior and the Value-Belief-Norm Theory explaining willingness to pay for a suburban park. Journal of Environmental Management, 113, 251-262.

Malaysian Conservation Alliance for Tigers (2012). MYCAT Tracks: Vol. 4. Malaysia: Petaling Jaya.

Matsiori, S K (2020). Application of the new environmental paradigm to Greece: A critical case study. Economic Analysis and Policy. doi:10.1016/j.eap.2020.02.010.

Mayer, F S, \& Frantz, C M (2004). The connectedness to nature scale: A measure of individuals' feeling in community with nature. Journal of Environmental Psychology, 24(4), 503-515.
Miller, L R, Dickinson, J E, \& Pearlman-Houghie, D J (2001). Quiet enjoyment in the National Parks of England and Wales: Public understanding of the term and its influence on attitudes towards recreational activities. Leisure Studies, 20(1), 19-40.

Montaguti, F, \& Mingotto, E (2015). Ecotourism in natural parks: An assured sustainable success? Tourist behavior, attractiveness and sustainable development issues in two Italian parks. Tourism Planning \& Development, 12(1), 99-110.

Moreto, W D, \& Lemieux, A M (2015). Poaching in Uganda: Perspectives of law enforcement rangers. Deviant Behavior, 36(11), 853-873.

Morrison-Saunders, A, Hughes, M, Pope, J, Douglas, A, \& Wessels, J A (2019). Understanding visitor expectations for responsible tourism in an iconic national park: Differences between local and international visitors. Journal of Ecotourism, 18(3), 284-294.

V. Nair Golf course development is now emerging as a major environmental issue in Asia. ECOCLUB (International Ecotourism Magazine ${ }^{\mathrm{TM}}$ ). Retrieved 20 July, 2013, fromhttp: //ecoclub.com/news/098/interview2.html2008

Novelli, M, Klatte, N, \& Dolezal, C (2017). The ASEAN community-based tourism standards: Looking beyond certification. Tourism Planning \& Development, 14(2), $260-281$.

Nurse, A (2015). Policing wildlife: Perspectives on the Enforcement of Wildlife Legislation. Cham, Switzerland: Springer.

Oishi, S, Schimmack, U, Diener, E, \& Suh, E M (1998). The measurement of values and individualism-collectivism. Personality and Social Psychology Bulletin, 24(11), 1177-1189.

Olson, J M, \& Zanna, M P (1993). Attitudes and attitude change. Annual Review of Psychology, 44, 117-154.

Pallant, J (2011). SPSS Survival Manual: A step by step guide to data analysis using SPSS (4th ed.). London: Allen \& Unwin.

Pickering, C, Rossi, S D, Hernando, A, \& Barros, A (2018). Current knowledge and future research directions for the monitoring and management of visitors in recreational and protected areas. Journal of Outdoor Recreation and Tourism, 21, 10-18.

Plumptre, A J (2019). Law enforcement for wildlife conservation. In Fang, F, Tambe, M, Dilkina, B, \& Plumptre, A J (Eds.), Artificial Intelligence and Conservation (pp. 17-28). Cambridge: Cambridge University Press.

Rakotomamonjy, S N, Jones, J P G, Razafimanahaka, J H, Ramamonjisoa, B, \& Williams, S J (2015). The effects of environmental education on children's and parents knowledge and attitudes towards lemurs in rural Madagascar. Animal Conservation, 18(2), 157-166.

Rasyikah, M K, Sulaiman, S S, Bakar, N A, \& Ab Rahman, S (2013). Revisiting legal framework for sustainable tourism in Taman Negara Malaysia. Research Journal of Applied Sciences, 8(8), 393-397.

Reid, A (2018). Curriculum and Environmental Education: Perspectives, Priorities and Challenges. London: Routledge.

Rokeach, M (1968). A theory of organizations and change in value-attitude systems. Journal of Social Issues, 24, 13-33.

Rollins, R, \& Robinson, D (2002). Social science, conservation, and protected areas. In Dearden, P, \& Rollins, R (Eds.), Parks and Protected Areas in Canada: Planning and Management (2nd ed., pp. 117-147). Don Mills, ON: Oxford University Press.

Schultz, P W (2001). The structure of environmental concern: Concern for self, other people, and the biosphere. Journal of Environmental Psychology, 21, 327-339.

Schultz, P W, Shriver, C, Tabanico, J J, \& Khazian, A M (2004). Implicit connections with nature. Journal of Environmental Psychology, 24(1), 31-42.

Schultz, P W, \& Zelezny, L (1999). Values as predictors of environmental attitudes: Evidence for consistency across 14 countries. Journal of Environmental Psychology, 19, 255-265.

Schwartz, S H (1973). Normative explanations of helping behavior: A critique, proposal, and empirical test. Journal of Experimental Social Psychology, 9(4), 349-364.

Schwartz, S H (1977). Normative influences on altruism. Advances in Experimental Social Psychology, 10, 221-279.

Schwartz, S H (1992). Universals in the content and structure of values: Theoretical advances and empirical tests in 20 countries. In Zanna, M (Ed.), Advances in experimental social psychology (pp. 1-65). Orlando, FL: Academic Press.

Schwartz, S H (1994). Are there universal aspects in the structure and contents of human values? Journal of Social Issues, 50(4), 19-45.

Schwartz, S H, \& Bilsky, W (1987). Toward a psychological structure of human values. Journal of Personality and Social Psychology, 53, 550-562.

Schwartz, F, Taff, B D, Lawhon, B, Hodge, C, Newman, P, \& Will, E (2018). Will they leave what they find? The efficacy of a leave No trace education program for youth. Applied Environmental Education and Communication, 17(4), 299-309.

Shao, W (2017). Weather, climate, politics, or god? Determinants of American public opinions toward global warming. Environmental Politics, 26(1), 71-96.

Spini, D (2003). Measurement equivalence of 10 value types from the Schwartz value survey across 21 countries. Journal of Cross-Cultural Psychology, 34(1), 3-23.

Steg, L, Dreijerink, L, \& Abrahamse, W (2005). Factors influencing the acceptability of energy policies: A test of VBN theory. Journal of Environmental Psychology, 25, $415-425$.

Stern, P C (2000). Toward a coherent theory of environmentally significant behavior Journal of Social Issues, 56(3), 407-424.

Stern, P C, Dietz, T, Abel, T, Guagnano, G A, \& Kalof, L (1999). A value-belief-norm theory of support for social movements: The case of environmentalism. Human Ecology Review, 6(2), 81-97.

Stern, P C, Dietz, T, \& Guagnano, G A (1995). The new environmental paradigm in social psychological perspective. Environment and Behavior, 27, 723-745.

Stern, P C, Dietz, T, Kalof, L, \& Guagnano, G A (1995). Values, beliefs and pro environmental action: Attitude formation toward emergent attitude objects. Journal of Applied Social Psychology, 25, 1611-1636. 
Stern, P C, Young, O R, \& Druckman, D (1992). Global environmental change: understanding the human dimensions. Washington, DC: National Academy Press.

Swami, V, Chamorro-Premuzic, T, Snelgar, R, \& Furnham, A (2010). Egoistic, altruistic, and biospheric environmental concerns: A path analytic investigation of their determinants. Scandinavian Journal of Psychology, 51, 139-145.

Swinnerton, G S (1999). Recreation and conservation: Issues and prospects. In Jackson, E L, \& Burton, T L (Eds.), Leisure Studies: Prospects for the Twenty-First Century (pp. 197-229). State College, PA: Venture Publishing.

Tabachnick, B G, \& Fidell, L S (2012). Using Multivariate Statistics (6th ed.). Pearson Education, Inc.

Thøgersen, J, \& Ölander, F (2002). Human values and the emergence of a sustainable consumption pattern: A panel study. Journal of Economic Psychology, 23, 605-630.

Toth, J F, \& Brown, R B (1997). Racial and gender meanings of why people participate in recreational fishing. Leisure Sciences: An Interdisciplinary Journal, 19, 129-146.

Tourism Malaysia. Retrieved 11.04.2014, fromwww.tourism.gov.my/en/kr/webpage/places/states-of-malaysia/pahang/taman-negara2014

Tverijonaite, E, Ólafsdóttir, R, \& Thorsteinsson, T (2018). Accessibility of protected areas and visitor behaviour: A case study from Iceland. Journal of Outdoor Recreation and Tourism, 24, 1-10.

Ulman, S R (2018). Study on general awareness regarding the problem of environmental degradation. CES Working Papers, 10(1), 1-26.

Vanhove, N (2010). The Economics of Tourism Destinations (2nd ed.). London: Routledge.
Verma, V K, Chandra, B, \& Kumar, S (2019). Values and ascribed responsibility to predict consumers' attitude and concern towards green hotel visit intention. Journal of Business Research, 96, 206-216.

Vimal, R, Gatiso, T, \& Mathevet, R (2018). Monitoring in tropical national parks: The power of knowledge. Conservation and Society, 16(1), 76-90.

Wearing, S, \& Neil, J (2009). Ecotourism: Impacts, Potentials and Possibilities. Oxford: Elsevier.

Weaver, D (2006). Sustainable tourism:Theory and practice. Oxford: Elsevier.

West, P C, Fly, J M, Larkin, F, \& Marans, R W (1992). Minority anglers and toxic fish consumption: Evidence from a statewide survey of Michigan. In Bryant, B, \& Mohai, $\mathrm{P}$ (Eds.), Race and the incidence of environmental hazards: A time for discourse (pp. 100-113). Boulder, CO: Westview Press.

Widegren, Ö (1998). The new environmental paradigm and personal norms. Environment and Behavior, 30, 75-100

Wildes, F T (1998). Influence of ecotourism on conservation policy for sustainable development: The case of Costa Rica. Doctor of Philosophy, University of California Santa Barbara and San Diego State University.

Wildlife Conservation Society. Retrieved 23.09, 2013, fromhttp://www.wcs.org/where-

we- work/asia/malaysia.aspx2013

Wright, P, \& Rollins, R (2002). Managing the national parks. In Dearden, P, \& Rollins, R (Eds.), Parks and protected areas in Canada: Planning and management (2nd ed., pp. 207-239). Don Mills: ON: Oxford University Press. 